\title{
MONETARY TRANSMISSION MECHANISM UNDER DUAL FINANCIAL SYSTEM IN INDONESIA: CREDIT-FINANCING CHANNEL
}

\author{
Reza Jamilah Fikri \\ STEI Tazkia, Sentul Bogor, Indonesia. Email: reza10jamilah@gmail.com
}

\begin{abstract}
Islamic and conventional banking in the dual financial system of Indonesia equally play an important role as financial intermediary, in that banks theoretically collect funds from the depositors and distribute to the financing clients/customers. However, over the years there has been a development in the financial industry, when financial deregulation occurs, where the role of providing credit is not only owned by the banks, but also other financial institutions. As a result, banks are no longer considered as the center of financial intermediation but could be replaced by other financial institutions. This study aims to reconsider the role of banking as financial intermediation in the monetary transmission mechanism using three methodological approaches: Vector Autoregression and Vector Error Correction Model (VAR-VECM), Error Correction Model (ECM), and Autoregressive Distributed Lag (ARDL). The long-term results of ECM and VECM estimations both show that credit and financing channels are still relevant to be employed in the monetary transmission mechanism after the development of financial sector and the change of monetary policy. However, they only have an impact to economy and do not give effect to inflation. While the result of ARDL estimation indicates that none of the variables affects the monetary policy objectives, which means that credit and financing channels are considered to be getting weaker in the monetary transmission mechanism.
\end{abstract}

Keywords: Monetary Transmission Mechanism; Credit Channel; Dual Financial System. JEL Classification: E51; E52; E58.

Received : September 27, 2018

Revised : October 27, 2018

Accepted : November 28, 2018 


\section{INTRODUCTION}

The issuance of Islamic Banking Act No 21 Year 2008 marks the enactment of Islamic financial system in Indonesia, resulting in the establishment of Islamic financial institutions along with the conventional financial institutions that operates earlier. Such a matter is to be called dual financial system. After the application of these two systems, Islamic and conventional banking systems synergically support broader mobilization of public fund in order to improve the financing contribution to national economic growth (Sharia Banking, 2018).

Islamic and conventional banking in the dual financial system of Indonesia equally hold the role as financial intermediary, meaning theoretically banks collect fund from the depositor and distributed to the financing clients/customers. However, over the years there has been a development in the financial industry, when financial deregulation occurs, where the role of providing credit is not only owned by the banks but also other financial institutions. The role of banks in advancing credit in the 1990s is considered not as important as it was in the 1950s to 1970s era (Mishkin, 1995). Thus, banks are no longer considered as the center of financial intermediation, as they could be replaced by other financial institutions, such as capital market, microfinance (cooperative), crowd funding, and many others. Because of the importance of banking sector and financial market role, financial market such as the capital market has a significant effect on the banking sector and the credit sector (Lerskullawat, 2016).

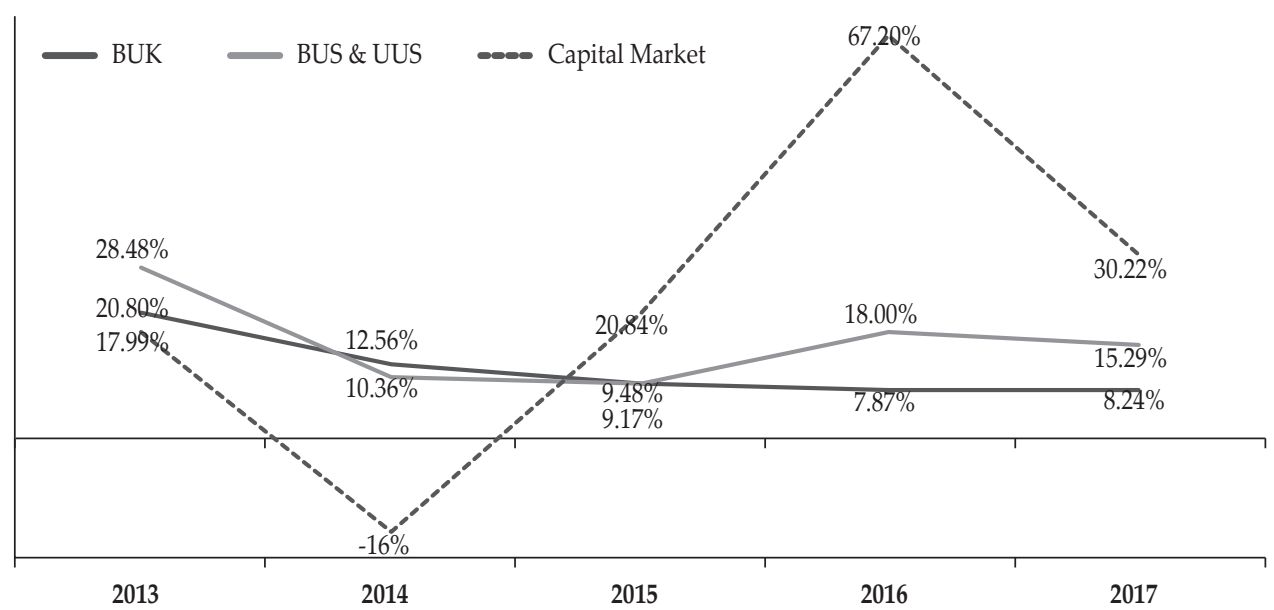

Source: spi, sps, capital market statistic. www.ojk.go.id, processed

Figure 1. Credit/financing development of Conventional banks, Islamic banks, business units, and Capital Market 2013-2017

As shown in Figure 1, credit/financing through the capital market has experienced fluctuating growth over the past five years by $30.22 \%$. Its growth is still above the growth of bank credit, especially conventional banking credit which only grew $8.24 \%$ at the end of 2017, which indicates that the public, with the large companies in particular, prefers to choose the capital market as their source of 
capital rather than applying credit or financing to the bank. Subsequently, along with the development of technology, there have been numerous start-ups in the financial industry engaged in financing. Governments all over the world have shown their concern about such a challenge and designed policies and regulations to support the financial technology (FinTech) development. The landscape of FinTech itself is mapped in eight categories, including payment, insurance, planning, crowd funding lending, block chain, trade and investment, data and analysis, as well as security. The rapid development of the FinTech landscape itself is located in the landscape of the payment, so that the public are getting used to non-cash transactions, crowd funding or peer-to-peer lending that could replace the role of banks (Loureiro and Gonzalez, 2015). Lending through FinTech could meet the credit that banks cannot extend (Jagtiani and Lemieux, 2018). Such a phenomenon has been developing since the 2008 crisis, where at that time many banks refused to lend to small and medium-sized businesses, creating channels for business loans to fill the gap not fulfilled by the banks (Ahmed and Beck, 2015).

Global FinTech industry development has significantly grown. It is noted that in Europe FinTech-based financing between 2013-2015 grows by $80 \%$ then it is projected in 2025 the total amount of FinTech-based financing will reach 395,682 million euros (European Central Bank, 2016). The development of global FinTech is also expected to reach Compound Annual Growth Rate (CAGR) of 51\% until 2020 (Morgan Stanley Research). In Indonesia, as stated by OJK up to March 2018 there have been 40 FinTech-based lending service providers registering in and obtaining permission from OJK.

FinTech transaction of Indonesia in 2017 was estimated reaching US\$ 18,65 billion. This amount is expected to soar to US\$ 37,15 billion in 2022, with CAGR of 2017-2021 peaking at 18,8\%. Large population and the society that has not been reached before by financial institutions are some forms of challenge for FinTech start-up in the country (Databoks, 2017). Despite impressive growth in recent years, the FinTech industry is still relatively small compared to the traditional banking sector. Under current circumstances, FinTech still has no influence to monetary transmission. However, FinTech's innovation has the potential to uphold the shift in credit intermediation from commercial banks to non-bank institutions of the financial system (Bernoth and Gebauer, 2017).

This shows that there will be a de-channel in the existence of banks in the credit channel, whereas the banking credit sector is one of the pathways considered effective in transmitting monetary policy to the economy. Bank credit channels are still effectively used in the monetary transmission mechanism in countries where banks and companies have minor direct access to financial markets (Peek and Rosengren, 2013).

Meanwhile, since 2016 the government has changed the policy rate for benchmark interest rate that affect the market by no longer using interest rates of SBI/SBIS, whereas from some previous literature the researchers used SBI/SBIS interest rates as one of variables to measure the monetary transmission mechanism in Indonesia. According to Montes and Monteiro (2014), monetary policy and prudential regulations could affect the aggregate investment through bank loan channels. 
In channel with the development of the financial sector in the dual financial system in Indonesia, it is important to identify the existence of the bank-lending channel. With all that said, based on the background it can be concluded that the purpose of this study is in twofold: (1) identification of the existence of conventional bank credit channels, and Islamic bank financing channels in the monetary transmission mechanism after the development of the financial sector and changes in monetary policy in Indonesia; and (2) an analysis of the influence of conventional bank credit channels, and Islamic banks financing channels for monetary policy objectives (economic growth and inflation).

\section{LITERATURE REVIEW}

Growth of the real sector cannot be separated from the intervention of government policies to achieve the targeted objectives, which one is by monetary policy. As stated by Warjiyo (2003) monetary policy is the action of the government (Central Bank) to control the money supply in the economy, which is basically an integral part of economic policy. Then, according to Mishkin (2006), monetary policy is the action of the central bank in influencing interest rates, the amount of credit, and the amount of money supply that will affect certain economic goals (high employment figures, economic growth, price stability, interest rate stability, financial market stability and exchange rate stability).

Monetary policy is considered important because policies issued by the Central Bank can affect the growth of interest rates, the amount of credit and the money supply which in turn not only affects the development of financial markets, but also the economic growth, inflation, and public welfare in general (Warjiyo, 2003). (Mishkin, 1999) stated there are four monetary policies, as shown in Table 1.

Table 1.

Types of Monetary Policies (Mishkin, 1999)

\begin{tabular}{lcc}
\hline Policy & Instrument & Target \\
\hline Inflation Targetting & Overnight Rate & Set Inflation Rate \\
Monetary Targetting & Money Supply Growth & Set Inflation Rate \\
$\begin{array}{l}\text { Exchange Rate Targetting } \\
\text { Monetary policy that is not set at } \\
\text { certain targets (Just Do It) }\end{array}$ & Spot Currency & Spot Currency \\
\hline
\end{tabular}

The influence process of the monetary sector to the economic sector is called the monetary transmission mechanism, or more specifically according to Taylor (1995) the mechanism of monetary transmission is "The process through which monetary policy decisions are transmitted into changes in real GDP and inflation". There are various studies regarding to the channel of monetary transmission mechanism, Mishkin (1995) divided conventional monetary transmission channels into 4 channels, namely interest rate channels, credit channels, exchange rate channels, and asset price channels. Meanwhile Warjiyo (2003) divided conventional monetary transmission channels into 5 channels by increasing the expected path. Above all monetary transmission channels, credit channel is considered as the best 
channel to connect the real sector and the monetary sector. For this reason, studies on the mechanism of monetary transmission of credit channel are important.

The approach of monetary policy transmission mechanism through credit channels is based on the assumption that not all public deposits in the form of money (M1, M2) are distributed by banks to the public in the form of credit. In other words, the banking intermediary function does not always run perfectly which means that an increase in public savings is not always followed by a proportional increase in credit disbursed to the public. The more influential to the real economy is bank credit, not public savings (Pohan, 2008). Meanwhile, according to Mishkin (1995), the credit channel arises due to the dissatisfaction from interest rates channel that are unable to explain the impact of monetary policy on long-term asset spending. This dissatisfaction led to the emergence of a new perspective on monetary transmission mechanism that emphasized the existence of asymmetric information and contracts with large costs that caused agency problems in financial markets.

In the Islamic economic, the banking sector does not recognize interest rate instruments. The Islamic financial system implements profit-loss sharing (PLS) based transaction and trend based transaction. The distribution proportion of profits obtained based on business activities (investment) and the provision of funds to the real sector. This means that the Islamic monetary system (monetary policy) has a dependency on the real sector (Nasution, 2006). Nevertheless, there are no specific Islamic principles discussing the monetary transmission mechanism regarding credit and financing channels. The central bank uses monetary policy in order to encourage economic growth by maintaining a smooth circulation of money in the medium and long term, within the framework of stable prices and other socioeconomic targets (Chapra, 2000).

Previous research on the mechanism of monetary transmission, especially bank lending channels, has been carried out, such as the research conducted by Ascarya (2012), (Wulandari, 2012), Yarasevika, Tongato, \& Muthia (2015), and Amaluddin (2007) economic growth in Indonesia. other studies such as Agha, et al. (2005), Simpasa, et al. (2015), Montes \& Monteiro (2014), and Sanfilippo-Azofra, et al. (2017), stating that the credit channel is very effective used in monetary transmission mechanisms that affect economic growth in 33 developing countries.

However, research on the mechanism of Islamic monetary transmission, especially the new bank financing channel was conducted recently and is still very limited, studies on bank financing channels including Amaluddin, (2007), Ascarya (2012), and Hamza and Saadaoui (2017) found that although the influence of the Islamic monetary system is still relatively small compared to the conventional system in transmitting monetary policy to the real sector, the Islamic system can reduce the adverse impact of interest rates, so it will not cause inflation and increase economic growth.

Ascarya (2012) uses the methods of VAR, ECM, and ARDL and argues that conventional systems provide the expected results, except that the increase in interest rate (rSBI) will increase inflation. The Islamic system mostly provides the expected results similar to conventional systems. The dual system still indicates some inconclusive results. 
Wulandari (2012) uses the SVAR method to pinpoints that the interest rate channel has a more significant effect on inflation, but has a smaller influence on the economy. Conversely the credit channel has a more significant effect on the economy.

Furthermore, Yarasevika et al., (2015) shows that the influence of reserves requirements (RR), loan interest rates (RC), consumer price index (INF), and real GDP on Bank Loans in the short term has a positive and negative effect. In the short-term real GDP, RR and INF have a positive effect on BL, while BL is negatively affected by RC based on the results of VECM analysis. Banks need to reduce lending rates to increase investment. Reserve requirements (RR), loan interest rates (RC), consumer price index (INF) must be made lower to increase Bank Loans (BL). Amaluddin (2007) maintains that conventional banks are more effective in transmitting monetary policy to the real sector of the economy than Islamic banks.

Agha et al., (2005) claims that future expectations of the role of credit channels will increase, especially due to financial sector reformation and the continuance of private sector credit expansion. Conversely, dependence on bank finances must decrease because the capital market becomes more developed. However, given the fact that the development of capital markets tends to occur gradually and increase emphasis on small and medium-sized businesses in Pakistan, the overall effect in the medium term should be an increase in the significance of bank lending channels.

Research by Montes and Monteiro (2014) in Brazil with the VAR method provides results that the monetary policy and prudential regulations affect aggregate investment through bank loan channels. The results show that credit is very sensitive to the effects of economic activities mainly from regulations. The results show that credit is very sensitive to economic activities mainly from regulation. In addition, it is estimated that employers' expectations and credit supply are stronger in influencing aggregate investment.

Moreover, Hamza and Saadaoui (2017) indicate that with the VAR and Panel Regression methods results that the presence of a monetary policy debt financing channel since variations in interest rates affects Islamic bank financing in Turkey, making growth of Profit-Sharing Investment Accounts (PSIA), capitalization, liquidity and asset size as one of the main determinants of the supply of Islamic bank's debt assets. In addition, using several resilience tests, it was found that, in addition to asset liquidity and bank size, the PSIA growth rate significantly reduced the negative impact of interest rates on the growth of debt financing, which highlighted the importance of this particular category of deposits in monetary transmission especially for countries where Islamic and conventional banking systems coexist.

\section{METHODOLOGY}

\subsection{Type and Source of Data}

This study uses monthly quantitative time series data from January 2008 to December 2017 obtained from various sources, including Badan Pusat Statistik (BPS), Bank Indonesia (BI), Statistik Ekonomi and Keuangan Indonesia (SEKI), 
Statistik Perbankan Indonesia (SPI), Statistik Perbankan Islamic (SPS), and Financial Service Authority (OJK).

\subsection{Research Methods}

This paper is a quantitative analysis using Error Correction Model (ECM), Vector Autoregression and Vector Error Correction Model (VAR-VECM), and Autoregression Distributed Lag (ARDL) approaches to get stronger results. Error Correction Model (ECM) is one of the dynamic models widely and intensely applied in economic analysis. This model aims to overcome the problem of time series data that is not stationary and spurious regression. Spurious regression is a regression equation that occurs due to the dependent variable, and the independent variable used to determine the regression is not stationary, and or the formation of the variable does not correlate substantially. The general form of the error correction model is as follows:

$$
\Delta y_{t}=\alpha_{0}+\alpha_{1} \Delta z_{t}+\gamma e_{t-1}+\varepsilon_{t}
$$

or

$$
\Delta y_{t}=\alpha_{0}+\alpha_{1} \Delta z_{t}+\gamma\left(y_{t-1}-\beta_{0}-\beta_{1} z_{t-1}\right)+\varepsilon_{t}
$$

Where $\alpha 1$ is the short-term coefficient and $\gamma$ is the coefficient of adjustment or error correction term (ECT).

According to Cristoper A Sims, if there is a true simultaneity between a set of equation variables, they must all be treated equally; there should be no apriori differences between endogenous and exogenous variables. In this spirit, Sims developed the VAR model: autoregressive vector model. The term autoregressive is a result of the lagging value appearance of the dependent variable on the right side, and the term vector is due to the fact that we deal with a vector of two (or more) variables (Gujarati, 2004). Enders (2004) formulates the VAR equation model as follows:

$$
Y_{t}=A_{0}+A_{1} Y_{t-1}+A_{2} Y_{t-1}+\ldots+A_{p} Y_{t-p}+\varepsilon_{t}
$$

Where:

$P \quad=$ Number of Variables in the equation system

$A_{0}=$ Vector $(\mathrm{n} \times 1)$ which contains $\mathrm{n}$ of each variable in VA

$A_{1}=$ Dimensional coefficient matrices $(\mathrm{n} \times \mathrm{n})$

$\varepsilon_{t}=$ Vector $(\mathrm{n} \times 1)$ of item error

ARDL is a model that is used to find out the present value and the value of the past (lag) in the free variable and become the explanatory variable in the non-independent variable. This model is very useful in empirical econometrics, because it makes static economic theory dynamic by calculating the role of the time explicitly. This model can distinguish short-term and long-term responses from variables not free from one unit of change in the value of explanatory variables (Gujarati, 2004). 
The ARDL method has several advantages over other cointegration testing methods. Unlike Engel-Grenger (1987), Johanson (1988) and Johanson and Juselius (1990) methods which require integrated variables in the same order, ARDL method can be used on variables with different integration orders. The ARDL method is also able to determine the direction of causality of the variables used in the model (Pesaran, M. H., Shin, 1999).

The general model of ARDL according to Pesaran and Shin (1999) is as follows.

$$
\begin{aligned}
& y_{t}=\alpha_{0}+\alpha_{1} t+\sum_{i=1}^{p} \emptyset_{i} y_{t-i}+\beta^{\prime} x_{t}+\sum_{i=0}^{q-1} \beta_{1}^{* \prime} \Delta x_{t-i}+u_{t} \\
& \Delta x_{t}=P_{1} \Delta x_{t-i}+P_{2} \Delta x_{t-2}+\ldots+P_{s} \Delta x_{t-s}+\varepsilon_{t}
\end{aligned}
$$

Where $x_{t}$ is a dimensioned variable $k$ on integration one 1 (1) which is not cointegrated between them, $u_{t}$ and $\varepsilon_{t}$ are disturbances/errors with zero mean), variants, and covariants are constant and uncorrelated. $P_{1}$ is the coefficient matrix $k \times k$ the process of vector autoregressive in $x_{t}$ is stable. It is also assumed that the root of $1-\sum \mathrm{i}=1{ }^{\wedge} \mathrm{p}$ term relationship between $y_{t}$ and $x_{t}$.

\subsection{Research Model}

The model used in this study adopts the Monetary Transmission Mechanism scheme on bank lending channel transformed in the model of Ascarya (2012) and modified by the author by eliminating the SBI/SBIS variables, as illustrated in Figure 2 as follows.

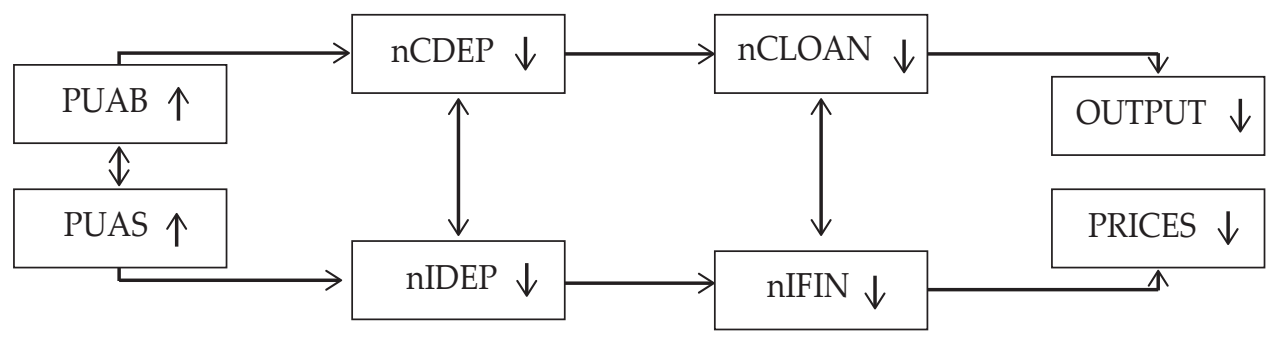

Figure 2. Research Model Framework

Where:

PUAB : Interbank Money Market interest rate;

PUAS : Islamic Interbank Money Market interest rate;

nCDEP : conventional deposit amount; nIDEP: the amount of Islamic deposits;

nCLOAN : the amount of conventional credit;

nIFIN : the amount of Islamic financing; Output: industry Price Index;

Prices : Inflation. 
For the research model, the author uses a model based on research by Ascarya (2011) without using SBI and SBIS variables, because monetary policy for reference interest rates on the money market does not use SBI and SBIS interest rates.

The ECM Models, include:

- Conventional model:

IPI-INF $=f(\mathrm{nCLOAN}, \mathrm{nCDEP}, \mathrm{PUAB})$

- Islamic Model:

$\mathrm{IPI}-\mathrm{INF}=f(\mathrm{nIFIN}, \mathrm{nIDEP}, \mathrm{PUAS})$

- Dual Model:

IPI-INF $=f(\mathrm{nIFIN}, \mathrm{nCLOAN}, \mathrm{nIDEP}, \mathrm{nCDEP}$, PUAS, PUAB)

The VECM Models, include:

- Conventional model:

Output: $X_{-} \mathrm{t}=(\mathrm{nCLOAN}, \mathrm{nCDEP}, \mathrm{PUAB}, \mathrm{IPI})$

Prices: $\mathrm{X} \_\mathrm{t}=(\mathrm{nCLOAN}, \mathrm{nCDEP}, \mathrm{PUAB}, \mathrm{INF})$

- Islamic Model:

Output: $X_{-} \mathrm{t}=(\mathrm{nIFIN}, \mathrm{nIDEP}$, PUAS, IPI)

Prices: $\mathrm{X} \_\mathrm{t}=(\mathrm{nCLOAN}, \mathrm{nCDEP}, \mathrm{PUAB}, \mathrm{INF})$

- Dual Model

Output: $X \_t=(n I F I N$, nCLOAN, nIDEP, nCDEP, PUAS, PUAB, IPI)

Prices: $X_{-} \mathrm{t}=(\mathrm{nIFIN}, \mathrm{nCLOAN}, \mathrm{nIDEP}, \mathrm{nCDEP}, \mathrm{PUAS}, \mathrm{PUAB}, \mathrm{INF})$

\section{RESULT AND ANALYSIS}

In this chapter the results of data processing are reported according to the methodology and economic analysis to answer the research objectives.

\subsection{Results of VAR-VECM Model}

\section{Stationarity Test}

There are several initial tests conducted in estimating the VAR-VECM model, including stationary test with unit root test, model stability test, optimum lag test, and cointegration test. The stationarity test itself is used to measure whether or not the data still contain trends. The method used in this stationarity test is the ADF (Augmented Dickey Fuller) and PP (Phillips-Perron) test. This study uses a $5 \%$ critical value with parameters if the $\mathrm{t}-\mathrm{ADF}$ value is smaller than the McKinnon critical value or a probability value less than 0.05 . It can be established that the data were stationary (does not contain unit roots). In this study all variables are not stationary in level, but they are all stationary in the first difference. 
Table 2.

Stationarity Test Results

\begin{tabular}{lcccc}
\hline \multirow{2}{*}{ VARIABLES } & \multicolumn{2}{c}{ ADF Probability Value } & \multicolumn{2}{c}{ PP Probability Value } \\
\cline { 2 - 5 } & Level & First Difference & Level & First Difference \\
\hline IPI & 0,8939 & 0 & 0,8423 & 0.0001 \\
INF & 0,1038 & 0 & 0,1960 & 0 \\
PUAB & 0,3377 & 0 & 0,3882 & 0 \\
PUAS & 0,1721 & 0 & 0,0025 & 0 \\
LnCDEP & 0,7392 & 0 & 0,7052 & 0 \\
LnIDEP & 0,0605 & 0 & 0,1941 & 0 \\
LnCLOAN & 0,1713 & 0 & 0,0487 & 0 \\
LnIFIN & 0,2914 & 0,0145 & 0,0853 & 0 \\
\hline
\end{tabular}

\section{Cointegration Test}

Table 3.

Cointegration Test Results

\begin{tabular}{|c|c|c|c|c|c|c|}
\hline Equation Model & & $\begin{array}{l}\text { Hypothesized } \\
\text { No. of CE(s) }\end{array}$ & Eigenvalue & $\begin{array}{c}\text { Trace } \\
\text { Statistic }\end{array}$ & $\begin{array}{c}0.05 \\
\text { Critical } \\
\text { Value }\end{array}$ & Prob.** \\
\hline \multirow[t]{4}{*}{ DUAL } & \multirow[t]{2}{*}{ IPI } & None* & 0.397546 & 180.7651 & 150.5585 & 0.0003 \\
\hline & & At most $1^{*}$ & 0.326081 & 121.4760 & 117.7082 & 0.0282 \\
\hline & \multirow[t]{2}{*}{ INF } & None* & 0.385941 & 168.6813 & 150.5585 & 0.0031 \\
\hline & & At most 1 & 0.256532 & 111.6246 & 117.7082 & 0.1139 \\
\hline \multirow[t]{6}{*}{ CONVENTIONAL } & \multirow[t]{2}{*}{ IPI } & None* & 0.349230 & 68.84525 & 55.24578 & 0.0020 \\
\hline & & At most 1 & 0.092859 & 18.58223 & 35.01090 & 0.7919 \\
\hline & \multirow[t]{4}{*}{ INF } & None* & 0.217699 & 56.44767 & 47.85613 & 0.0064 \\
\hline & & At most 1 & 0.099069 & 27.72237 & 29.79707 & 0.0852 \\
\hline & & At most $2^{*}$ & 0.069327 & 15.51618 & 15.49471 & 0.0496 \\
\hline & & At most $3^{*}$ & 0.058960 & 7.110088 & 3.841466 & 0.0077 \\
\hline \multirow[t]{6}{*}{ ISLAMIC } & \multirow[t]{2}{*}{ IPI } & None* & 0.276507 & 81.49924 & 63.87610 & 0.0008 \\
\hline & & At most $1^{*}$ & 0.196967 & 43.63055 & 42.91525 & 0.0423 \\
\hline & \multirow[t]{4}{*}{ INF } & None* & 0.280147 & 75.75473 & 47.85613 & 0.0000 \\
\hline & & At most $1^{*}$ & 0.157508 & 37.29590 & 29.79707 & 0.0057 \\
\hline & & At most $2^{*}$ & 0.096304 & 17.24317 & 15.49471 & 0.0270 \\
\hline & & At most $3 *$ & 0.045068 & 5.395449 & 3.841466 & 0.0202 \\
\hline
\end{tabular}

Table 3 shows that the Johansen cointegration summary test results in dual IPI and INF models, with the cointegration test being done using the fourth assumption: the intercept and trend. This test gives reveals that in the dual IPI model there are two cointegration equations at the level of 0.05 ; whereas, in the dual INF model there is one cointegration equation. 
As for the Johansen cointegration summary test for the conventional model of IPI, the cointegration test is carried out using the 5th assumption, Quadratic Intercept, and trend, which reveals that in the conventional IPI model there is 1 cointegration equation at the 0.05 level. At the same time, in the conventional INF model the cointegration test is carried out using the 5th Quadratic Intercept and trend assumptions, giving the result that there is no cointegration equation, yet by using the 3 rd assumption it results in 3 cointegration equations. Thus, for conventional models INF has 3 cointegration equations.

As far as the Johansen cointegration summary test for the Islamic IPI model is concerned, the cointegration test is carried out using the fourth assumption that is interest and trend. This test shows that in the Islamic IPI model there are 2 cointegration equations at the 0.05 level. Meanwhile in the INF Islamic model, the cointegration test is carried out using the 3rd assumption, that is the intercept no trend, yielding that in the INF Islamic model there are 4 cointegration equations.

\section{Granger Causality}

From the Granger Causality test it can be concluded that both variables of LnCLOAN (credit) and LnIFIN (financing) continuous to the output, but not to prices. This shows that both credit and financing channels are still widely used in the monetary transmission mechanism on monetary objective of output increase, but no longer can be used on monetary objective of inflation stability.

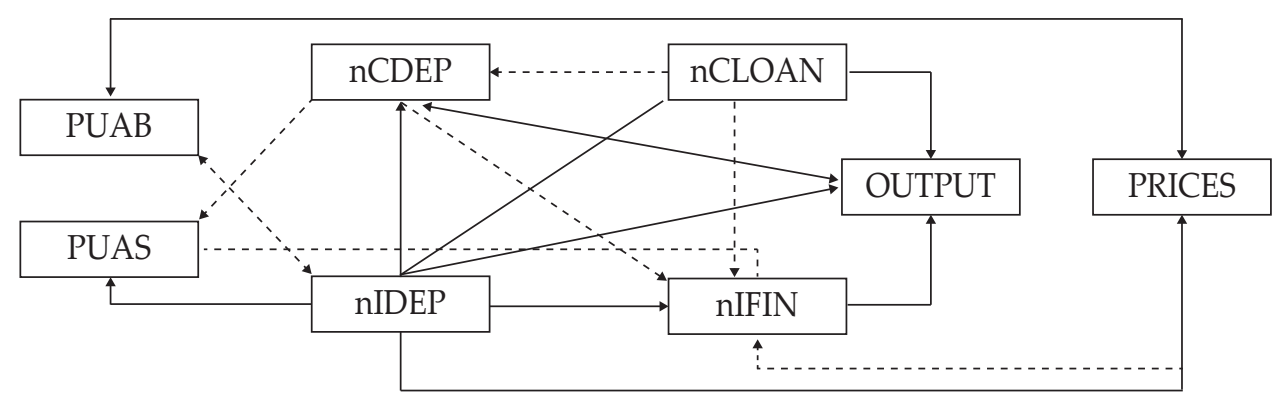

Figure 3. Granger Causality

\section{Impulse Response Function (IRF) and Forecast Error Variance Decomposition (FEVD)}

The results of the dual IPI IRF model (see Figure 4, left) show that the IPI variable responds positively to the shocks that occur in the LnIFIN, PUAS, and PUAB variables, but provides a negative response to the shock variables LnCLOAN, LnCDEP, and LnIDEP. Meanwhile, the results of the dual INF IRF model (see figure 4, right) show that the INF variable only gives a positive response to the shocks that occur in the LnIFIN variable but responds negatively to shocks that occur in the variables of LnCLOAN, LnCDEP, LnIDEP, PUAS, and PUAB. 
IRF IPI DUAL

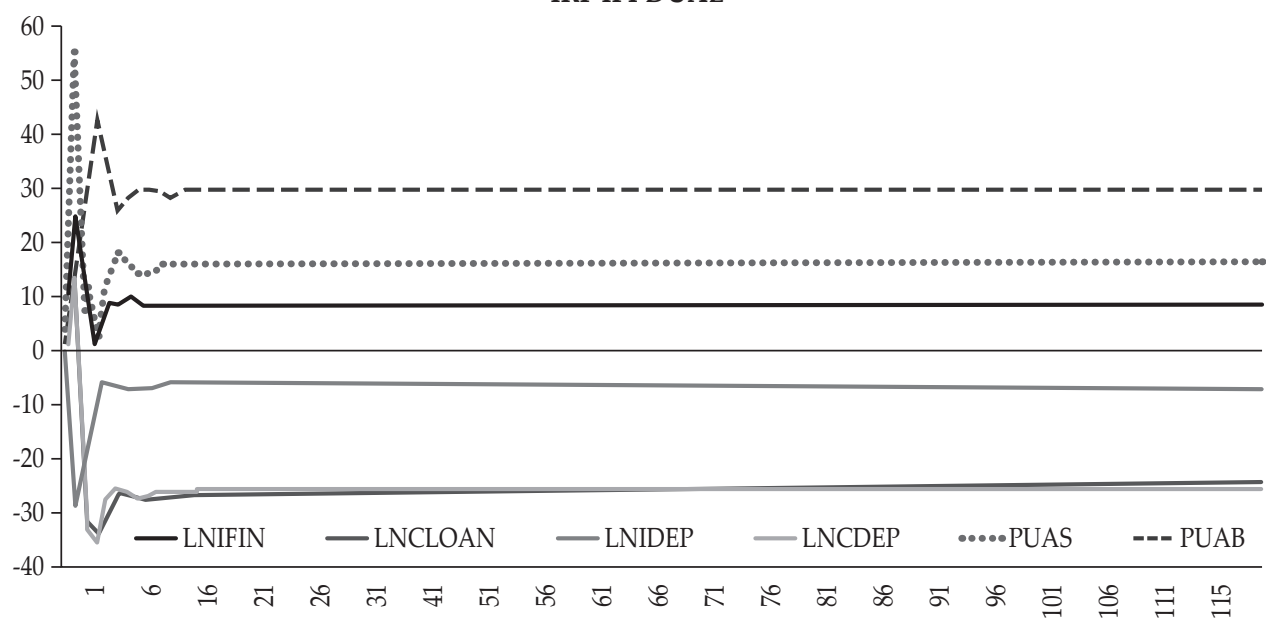

IRF INF DUAL

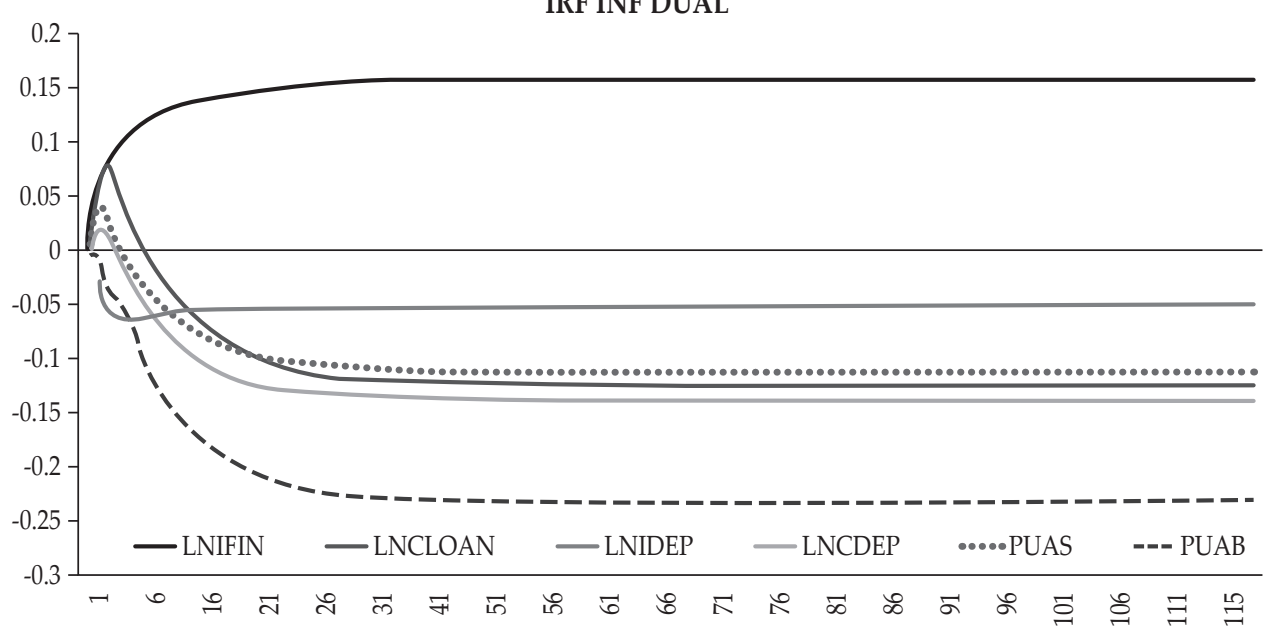

Figure 4. IRF of The Dual Model 
The magnitude of the influence or share of variables to IPI and INF can be seen in the FEVD results on figure 5.

FEVD IPI DUAL

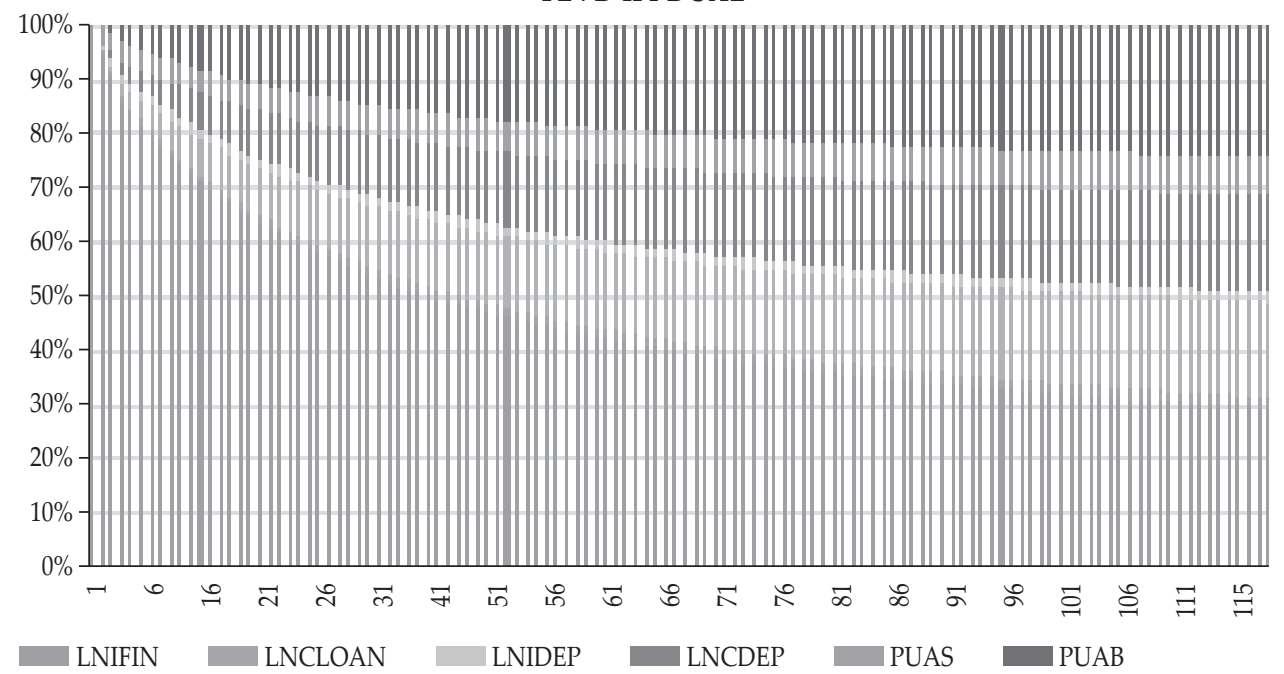

FEVD INF DUAL

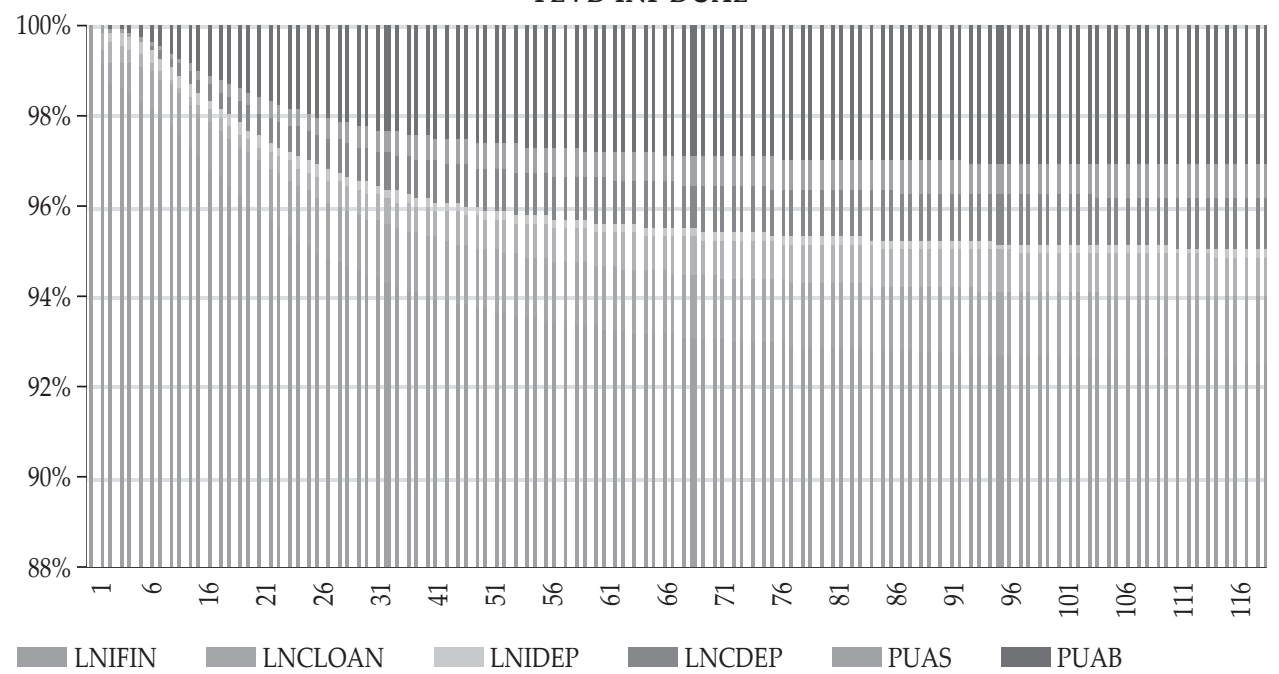

Figure 5. FEVD of The Dual Model

The dual model FEVD results for IPI (see Figure 5, left) show that conventional variables are dominant in influencing IPI, especially through PUAB interest rates. Meanwhile, the Dual model FEVD results of INF (see figure 5, right) show that conventional and Islamic variables have not been major factors in influencing INF, especially the Islamic variables. 

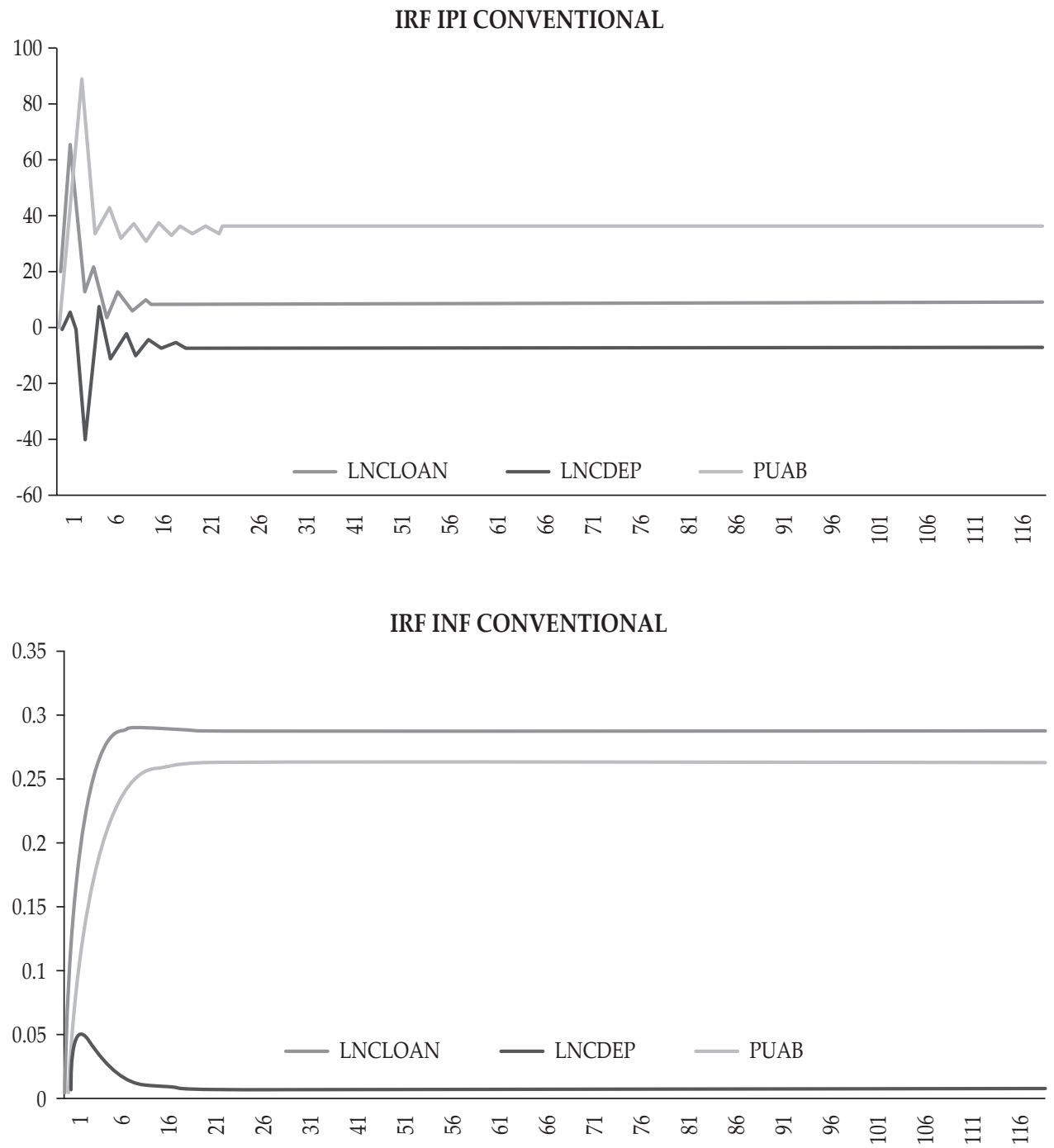

Figure 6. IRF of The Conventional Model

The IRF results of the conventional IPI model (see Figure 6, left) show that the IPI variable responds positively to shocks that occur in the LnCLOAN and PUAB variables, but provides a negative response to the LnCDEP variable shock. Meanwhile, the results of the conventional IRF model INF (see figure 6, right) show that the INF variable provides a positive response to shocks that occur in all variables (LnCLOAN, LnCDEP, and PUAB).

The magnitude of the influence or share of variables to IPI and INF can be seen in the FEVD results in Figure 7. 


\section{FEVD IPI CONVENTIONAL}

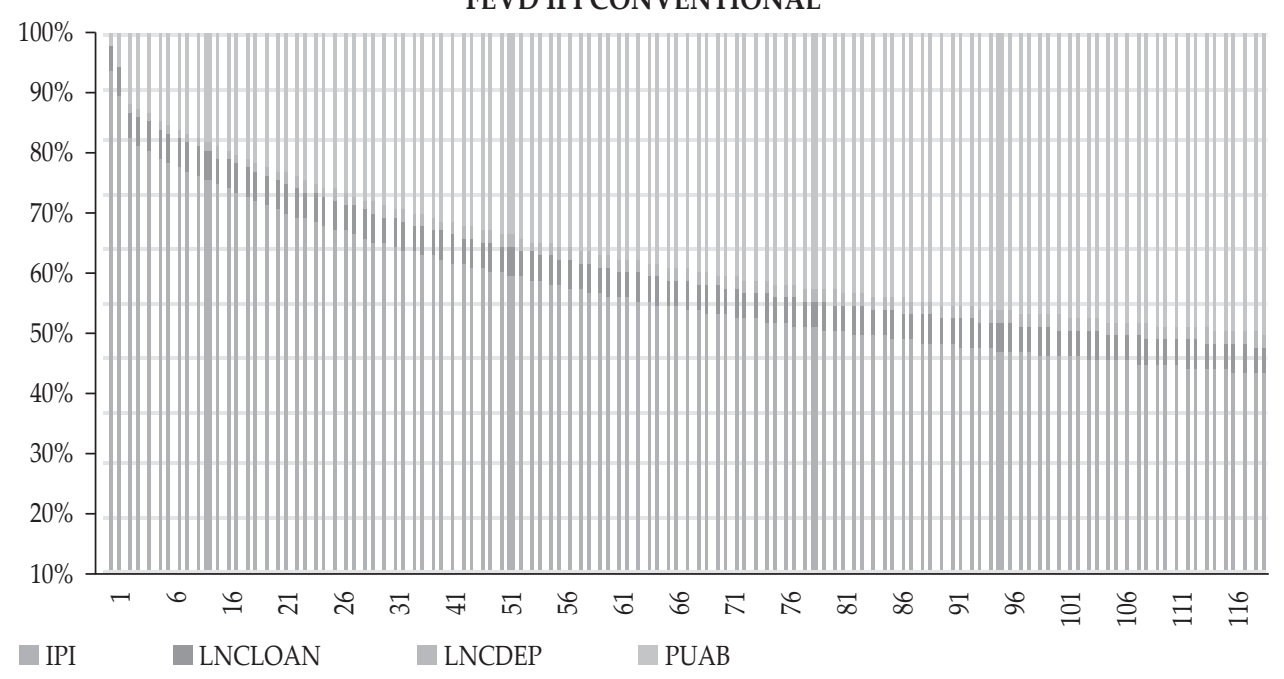

FEVD INF CONVETIONAL

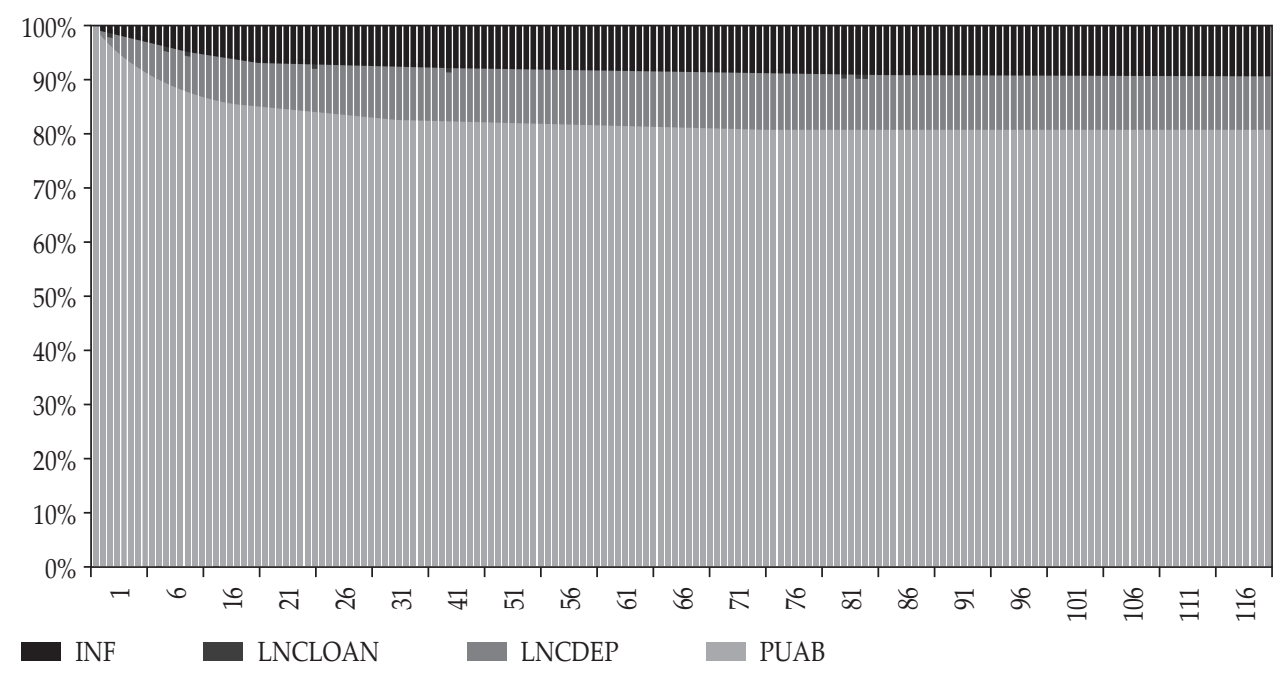

Figure 7. FEVD of The Conventional Model

The conventional model FEVD results of IPI (see figure 7, left) show that conventional variables have given major influence to IPI (62.97\%), especially through PUAB interest rates. Meanwhile, the conventional model FEVD results of INF (see figure 7, left) show that conventional variables have given minor influence to INF $(20 \%)$. 


\section{IRF IPI ISLAMIC}

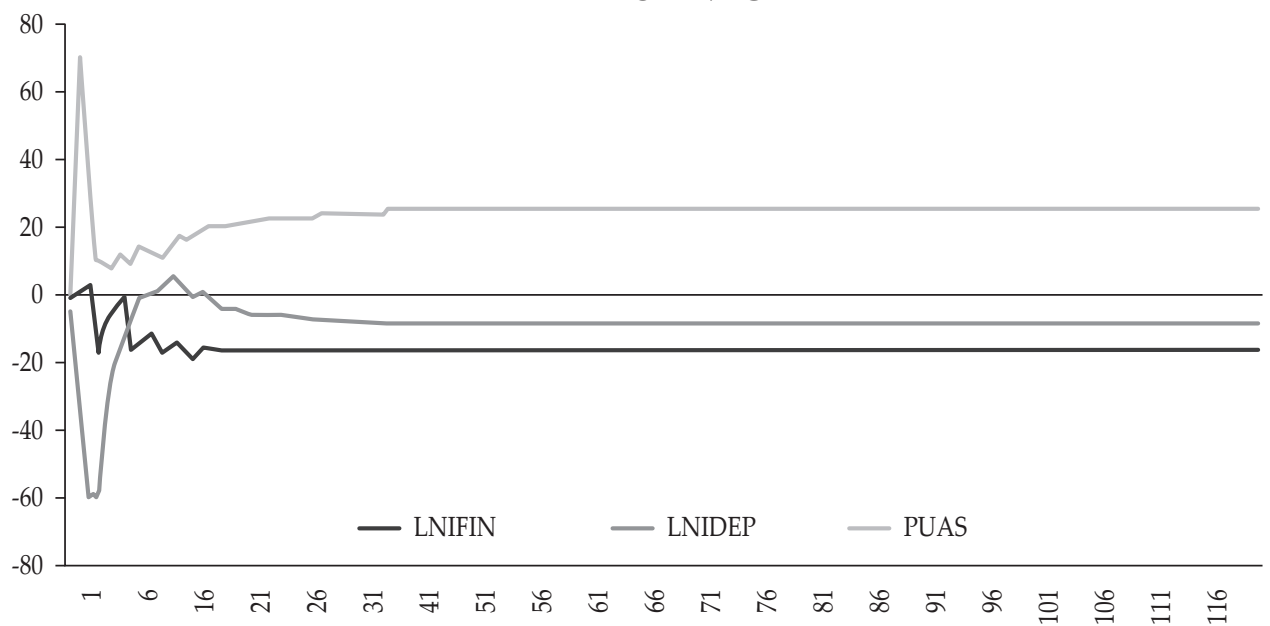

IRF INF ISLAMIC

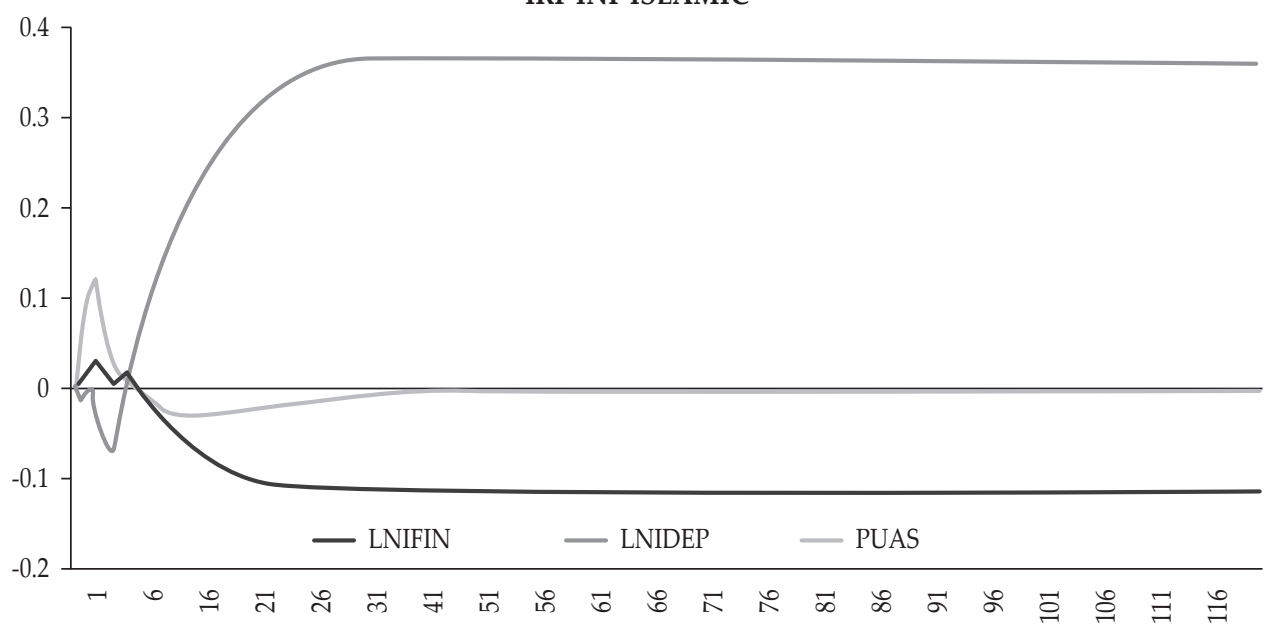

Figure 8. IRF of The Islamic Model

The IRF results of the Islamic IPI model show that the IPI variable responds positively to shocks that occur in the PUAS variable, but gives a negative response to the shocks of the LnIFIN and LnIDEP variables. Meanwhile, the results of the INF Islamic model IRF show that the INF variable gives a positive response to shocks that occur in all LnIDEP, but gives a negative response to the LnIFIN and PUAS variable shocks.

The magnitude of the influence between variables seen from the FEVD results as follows: 

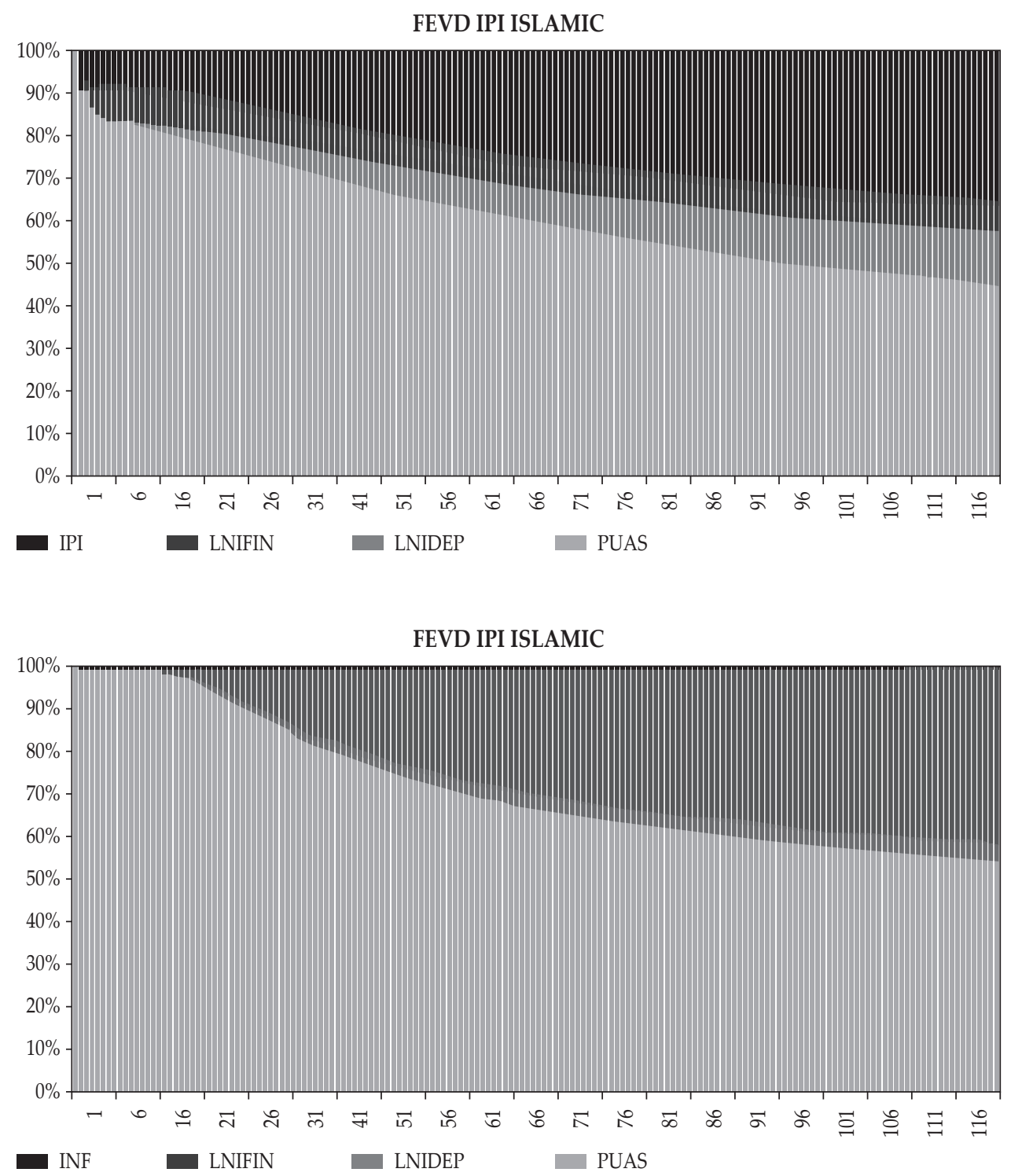

Figure 9. FEVD of The Islamic Model

IPI Islamic FEVD results show that Islamic variables have given major influence to IPI (53.69\%), especially through the PUAS margin. Meanwhile, the INF Islamic FEVD results show that the Islamic variables have dominantly affected the INF (45.15\%).

\subsection{Results of ECM Model}

The results of cointegration test for all IPI and INF equations, including dual model, conventional model and Islamic model, can be seen in Table 4 . 
Table 4.

ECM Cointegration Test Results

\begin{tabular}{llccc}
\hline EQUATION MODEL & & t-statistic & $\begin{array}{c}\text { McKinnon } \\
\text { Critical Value }\end{array}$ & Prob \\
\hline DUAL & IPI & -6.632682 & -2.885863 & 0.0000 \\
& INF & -3.910091 & -2.885863 & 0.0027 \\
\hline CONVENTIONAL & IPI & -3.109844 & -2.886290 & 0.0286 \\
& INF & -3.837670 & -2.885863 & 0.0034 \\
\hline ISLAMIC & IPI & -2.076580 & -2.886290 & 0.2545 \\
& INF & -3.585756 & -2.886074 & 0.0034 \\
\hline
\end{tabular}

This test was conducted to see the existence of a long-term relationship in the ECM equation model both IPI and INF. The table results show the cointegration of the two models except the Islamic IPI model by conducting unit root tests with the ADF test on the residual value of each model with a critical value of $5 \%$, which means if the probability value of parameter is less than 0.05 , then it can be ascertained that the independent variable significantly affects the dependent variable.

The results of ECM Estimation for the dual model, both IPI and INF, can be seen in Table 5.

Table 5.

Dual Model ECM Results

\begin{tabular}{|c|c|c|c|c|c|}
\hline \multirow{4}{*}{ VARIABLE } & \multirow{2}{*}{\multicolumn{2}{|c|}{$\begin{array}{c}\text { IPI } \\
\text { ECM }\end{array}$}} & \multirow{4}{*}{ VARIABLE } & \multirow{3}{*}{\multicolumn{2}{|c|}{$\begin{array}{c}\text { INF } \\
\text { ECM } \\
\text { Prob }\end{array}$}} \\
\hline & & & & & \\
\hline & \multicolumn{2}{|c|}{ Prob } & & & \\
\hline & $\begin{array}{l}\text { Short } \\
\text { Run }\end{array}$ & $\begin{array}{l}\text { Long } \\
\text { Run }\end{array}$ & & $\begin{array}{l}\text { Short } \\
\text { Run }\end{array}$ & $\begin{array}{l}\text { Long } \\
\text { Run }\end{array}$ \\
\hline LnIFIN & 0.1626 & 0.9901 & LnIFIN & 0.1134 & 0.0016 \\
\hline LnCLOAN & 0.3553 & 0.0810 & LnCLOAN & 0.5133 & 0.3796 \\
\hline LnIDEP & 0.3182 & 0.0509 & LnIDEP & 0.5052 & 0.2627 \\
\hline LnCDEP & 0.1490 & 0.0000 & LnCDEP & 0.4942 & 0.0000 \\
\hline PUAS & 0.1824 & 0.0185 & PUAS & 0.1447 & 0.6206 \\
\hline PUAB & 0.8628 & 0.3079 & PUAB & 0.4320 & 0.0000 \\
\hline ECT Coefficient & -0.526631 & & ECT Coefficient & -0.074750 & \\
\hline
\end{tabular}

The long-term results of ECM on the Dual IPI model (see Table 5, left) shows that conventional and Islamic variables contribute positively to the output (IPI) through the LnCDEP and PUAS variables, this means that the increase in LnCDEP and PUAS in the long term will increase IPI. Meanwhile, the dual INF model (see table 5, left) shows that conventional and Islamic variables contribute positively to inflation (INF) through the variables LnIFIN, LnCDEP and PUAB, this means that the increase in LnIFIN, LnCDEP and PUAB in the long term will increase the INF. Short-term estimation results show that all variables have no effect on IPI and INF. 
In addition, the Error Correction Term (ECT) on the IPI equation model is negative and smaller than one $(-0.526631)$ and significant at the $5 \%$ critical value. This shows that $52.66 \%$ of the irregularities are corrected every month, which means through the adjustment process (speed of adjustment) the deviation will be stable at 1.90 months. Meanwhile, the ECT in the INF equation model is negative and smaller than one $(-0.074750)$ and significant at the $5 \%$ critical value, this indicates that $7.48 \%$ of the deviations are corrected every month, which means through the adjustment process (speed of adjustment) the deviation will be stable at 13.36 months.

Table 6.

Conventional Model ECM Results

\begin{tabular}{|c|c|c|c|c|c|}
\hline \multirow{4}{*}{ VARIABLE } & \multicolumn{2}{|c|}{ IPI } & \multirow{4}{*}{ VARIABLE } & \multirow{2}{*}{\multicolumn{2}{|c|}{$\begin{array}{c}\text { INF } \\
\text { ECM }\end{array}$}} \\
\hline & \multicolumn{2}{|c|}{ ECM } & & & \\
\hline & \multicolumn{2}{|c|}{ Prob } & & \multicolumn{2}{|c|}{ Prob } \\
\hline & $\begin{array}{l}\text { Short } \\
\text { Run }\end{array}$ & $\begin{array}{l}\text { Long } \\
\text { Run }\end{array}$ & & $\begin{array}{l}\text { Short } \\
\text { Run }\end{array}$ & $\begin{array}{l}\text { Long } \\
\text { Run }\end{array}$ \\
\hline LnCLOAN & 0.1884 & 0.0700 & LnCLOAN & 0.0952 & 0.0000 \\
\hline LnCDEP & 0.1543 & 0.0000 & LnCDEP & 0.3804 & 0.0000 \\
\hline PUAB & 0.9570 & 0.0395 & PUAB & 0.5177 & 0.0000 \\
\hline Coefficient ECT & -0.477815 & & Coefficient ECT & -0.065627 & \\
\hline
\end{tabular}

The long-term ECM results on the conventional IPI model show that the variable contributing to the positive influence on output (IPI) is only the LnCDEP variable, which means that the increase in LnCDEP in the long run will increase IPI. Meanwhile, the INF conventional model shows that all variables contribute to a positive influence on inflation (INF), signifying the increase in LnCLOAN, LnCDEP, and PUAB in the long term will continue to increase the INF. Short-term estimation results show that all variables have no influence on INF.

In addition, the ECT of the IPI equation model is negative and smaller than one $(-0.477815)$ and significant at the $5 \%$ critical value. This shows that $47.78 \%$ of the irregularities are corrected every month, which means through the adjustment process (speed of adjustment) deviations will stabilize at 2.09 months. Meanwhile, the ECT of the INF equation model is negative, smaller than one (-0.065627), and significant at the $5 \%$ critical value, indicating that $6.56 \%$ of the deviations are corrected every month, which means through the adjustment process (speed of adjustment) the deviation will be stable at 15.24 months. 
Table 7.

Islamic Model ECM Results

\begin{tabular}{|c|c|c|c|c|c|}
\hline \multirow{4}{*}{ VARIABLE } & \multicolumn{2}{|c|}{ IPI } & \multirow{4}{*}{ VARIABLE } & \multirow{2}{*}{\multicolumn{2}{|c|}{$\begin{array}{l}\text { INF } \\
\text { ECM }\end{array}$}} \\
\hline & \multicolumn{2}{|c|}{ ECM } & & & \\
\hline & \multicolumn{2}{|c|}{ Prob } & & \multicolumn{2}{|c|}{ Prob } \\
\hline & $\begin{array}{l}\text { Short } \\
\text { Run }\end{array}$ & $\begin{array}{l}\text { Long } \\
\text { Run }\end{array}$ & & $\begin{array}{l}\text { Short } \\
\text { Run }\end{array}$ & $\begin{array}{l}\text { Long } \\
\text { Run }\end{array}$ \\
\hline LnIFIN & & 0.0292 & LnIFIN & 0.0189 & 0.0000 \\
\hline LnIDEP & & 0.6845 & LnIDEP & 0.7466 & 0.0000 \\
\hline PUAS & & 0.4270 & PUAS & 0.2146 & 0.0531 \\
\hline ECT Coefficient & & & ECT Coefficient & -0.032782 & \\
\hline
\end{tabular}

The long-term ECM Islamic model of IPI show that the variable that contribute to the positive influence on output (IPI) is only the variable of LnIFIN, this means that the increase in LnIFIN in long run will increase IPI. On the other hand, the INF Islamic model shows that variables contributing to a positive influence on inflation (INF) are the variables of LnIFIN and LnIDEP, which means that the increase of LnIFIN and LnIDEP in the long term will increase the INF. The IPI cointegration results show that the residual value is not stationary at the level, causing it unable to continue in the short-term test. Short-term estimation results show that all variables do not have an influence on INF.

In addition, the ECT of the INF equation model is negative and smaller than one $(-0.032782)$ and significant at the $5 \%$ critical value. This shows that $3.29 \%$ of the deviations are corrected every month, meaning through the adjustment process (speed of adjustment) deviations will be stable at 30.39 months or 2.5 years.

\subsection{Results of ARDL Model Estimation}

Table 8 shows the cointegration test results for all equations of all three models (dual, conventional and Islamic models). The table shows that all equation models have cointegration.

Table 8.

ARDL Cointegration Model Test

\begin{tabular}{llcl}
\hline Equation & & F - Statistics & Explanation \\
\hline DUAL & IPI & 2.63 & Cointegrated \\
& INF & 2.22 & Cointegrated \\
\hline CONVENTIONAL & IPI & 2.82 & Cointegrated \\
& INF & 2.67 & Cointegrated \\
\hline ISLAMIC & IPI & 4.81 & Cointegrated \\
& INF & 3.44 & Cointegrated \\
\hline
\end{tabular}

Meanwhile, the results of ARDL estimation of all equations can be seen in Table 9, applying the critical value of $5 \%$. 
Table 9.

ARDL Estimation Results

\begin{tabular}{lcccccc}
\hline \multirow{2}{*}{ Variable } & \multicolumn{2}{c}{ DUAL } & \multicolumn{2}{c}{ CONVENTIONAL } & \multicolumn{2}{c}{ ISLAMIC } \\
\cline { 2 - 7 } & IPI & INF & IPI & INF & IPI & INF \\
\hline LnIFIN & 0.08 & 0.31 & & & 0.98 & 0.28 \\
LnCLOAN & 0.99 & 0.81 & 0.43 & 0.24 & & \\
LnIDEP & 0.27 & 0.73 & & & 0.37 & 0.53 \\
LnCDEP & 0.58 & 0.72 & 0.49 & 0.39 & & \\
PUAS & 0.33 & 0.11 & & & 0.93 & 0.06 \\
PUAB & 0.78 & 0.66 & 0.80 & 0.36 & & \\
\hline
\end{tabular}

ARDL results show that all variables of all equation models have no significant influence on dependent variables (IPI and INF).

\subsection{Analysis}

The results of Dual IRF show that both of dual model give a positive response to LnIFIN. The Islamic variables (LnIFIN, LnIDEP, PUAS) tend to give more positive responses to economic (output) compared to the conventional variable (PUAS), while the conventional variables (LnCLOAN, LnCDEP, PUAB) are likely to give more negative influences to INF than the Islamic variables (LnIFIN, LnIDEP, and PUAS).

On the output model (IPI), LnIFIN gives positive influences to IPI, according to Abduh and Omar (2012) that the financing of Islamic Banking has a significant influence to economic growth of Indonesia. Such a notion is shared in the study by Kassim (2015), where Islamic financing gives important contribution to the real sector as well as the economy in Malaysia. As also stated in Boukhatem and Moussa (2018), Islamic financing could stimulate the economic growth in MENA (Middle Eastern and North Africa) countries.

Meanwhile, LnCLOAN gives a negative impact on the economy. According to Warjiyo (2004) this negative impact could be due to the financial sector fluctuation, where the domestic demand expansion occurs faster than the economic capacity.

Meanwhile, in the INF model, LnIFIN has a positive effect on inflation. This is consistent with the previous research conducted by Kia (2014), stating that in the Islamic economic system there is a possibility that Islamic financing could affect the inflation. For example, let's say there is a sudden increase in aggregate demand as a result of the escalation of population or urbanization that could cause inflation. The prices can also increase as a result of deteriorating domestic currency values. Inflation can also be imported because the value of imported goods or imported production factors increases. In addition, LnCLOAN has a negative effect on inflation and could be due to the interest-based conventional economy having two dichotomous markets, i.e., the financial market (SBI and PUAB) and the real market (LnCLOAN), where the market in the financial sector is inflationary (Ascarya, 2012).

Conventional results are in accordance with the research of Ascarya (2012) where in the output model, the flow of dual monetary policy transmission 
from the conventional side channeled to output, especially from credit, because conventional credit is part of activities in the real sector. Then, in the Inflation model, the flow of dual monetary policy transmission from the conventional side channeled to Inflation. This can be explained, among others, because the interestbased conventional economy has both the financial sector and real sector market markets as dichotomous markets and markets in the financial sector are inflationary in nature. Therefore, interest as the price in the conventional financial sector affects inflation. The results above generally show that conventional variables when separated from Islamic variables, primarily the variable of financial sector: naturally trigger inflation and effectively obstruct the economic growth (Hamza and Saadaoui, 2017).

In the IPI results, PUAS has a positive influence on IPI. This is in line with the research of Ascarya (2012) that the behavior of conventional interest rates and Islamic returns is indicated by the conventional interbank money market (PUAB) interest rates and Islamic interbank money market (PUAS) returns. In so doing, the PUAB interest rate is a reference for conventional banking interest rates, while the return of PUAS with mudharabah contract is based on the return in the real sector. The impact of interest rates and profit sharing on inflation is in accordance with the empirical study of Ascarya (2009) that highlights interest rates being one of the main causes of inflation, while profit sharing not causing inflation. Meanwhile, LnIFIN and LnIDEP have a negative effect on IPI, which is in line with Pratiwi (2016) study that the existence of business and objectives of Islamic banks do not correlate with Indonesia's economic goals. First, it can be due to the total assets of Islamic banking that are still low compared to the total assets of conventional banking. Second, the Islamic banking industry still provides a lot of financing in the form of consumption credit (Debt Financing). Third, the problem may arise from murabahah financing, which is not Shariah compliance (Wijaya, 2009) as seen in Figure 10:

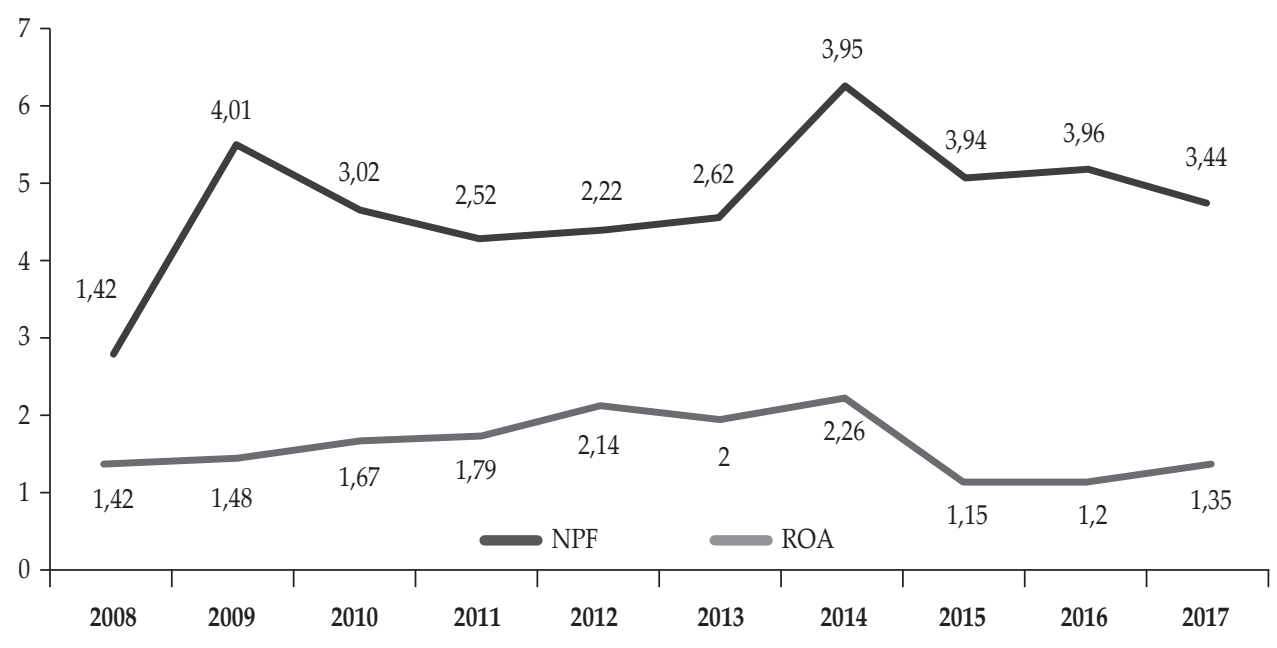

Source: Islamic Banking Statistic OJK, processed

Figure 10. Indonesia Islamic Banking Performance 2008-2017 


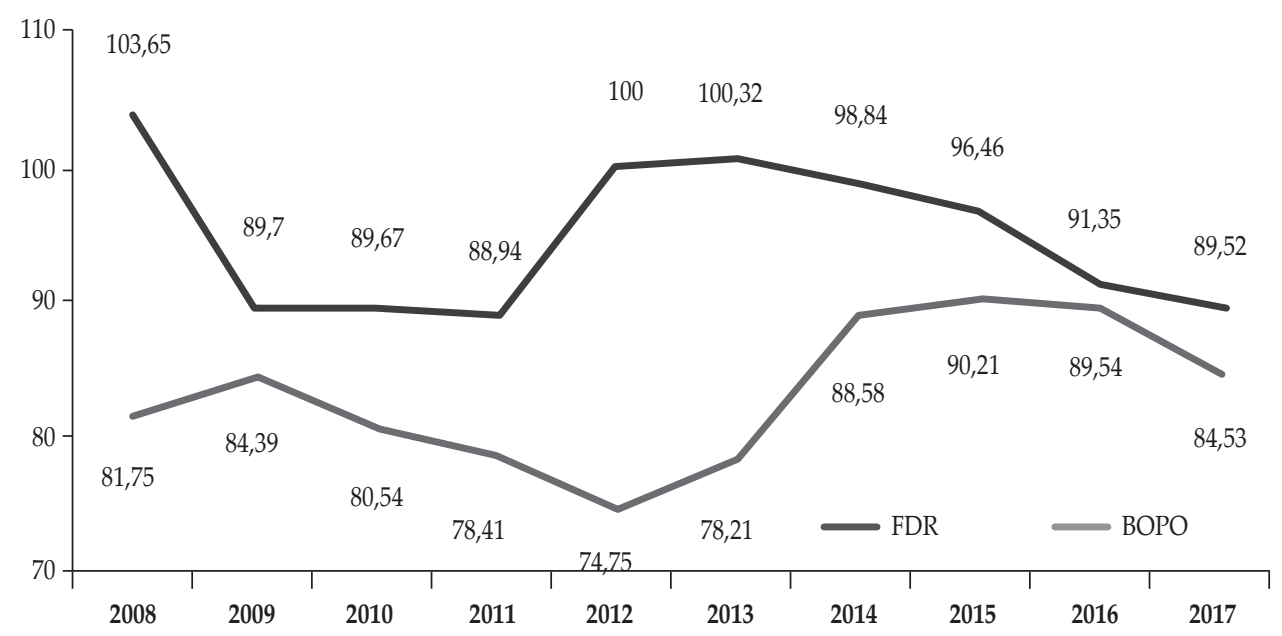

Source: Islamic Banking Statistic OJK, processed

Figure 11. Indonesia Islamic Banking Performance 2008-2017

Data in Figure 10 shows that the performance of Islamic banking began to decchannel since 2013, then rose in 2014 but then continued to decline. Thus, the decline in the performance of Islamic banking shows the declining contribution of Islamic banking financing to the economy.

In the INF results, LnIDEP has a positive effect on inflation. This is in accordance with the opinion of Nazib and Masih (2017) that Islamic banking deposits are also strongly influenced by the rate of inflation, which it turns to be the most exogenous variable among others to affect inflation.

As a potential channel for the monetary transmission mechanism in a dual system, Islamic financing can react directly to expansionary or contractionary monetary policy even though there is (or is not) Islamic monetary policy rates. In addition, if Islamic banks react appropriately to the objectives of monetary policy, it can prove an effective monetary transmission mechanism with the existence of financing channel. Islamic banks with quite high PSIA can minimize the influence of tightening monetary policy, which is mostly negative both from bank reserves and checking accounts through multiplier mechanism with credit consequences (Hamza and Saadaoui, 2017). Table 10 shows the summary results of all models applying ECM, ARDL and VECM methods. 
Table 10.

Overall Estimation Results

\begin{tabular}{|c|c|c|c|c|c|c|c|c|c|c|c|c|c|c|c|c|c|}
\hline \multirow{4}{*}{ VARIABLE } & \multicolumn{8}{|c|}{ CONVENTIONAL } & \multirow{4}{*}{ VARIABLE } & \multicolumn{8}{|c|}{ ISLAMIC } \\
\hline & \multicolumn{2}{|c|}{ ECM } & \multicolumn{2}{|c|}{ ARDL } & \multicolumn{4}{|c|}{ VECM } & & \multicolumn{2}{|c|}{ ECM } & \multicolumn{2}{|c|}{ ARDL } & \multicolumn{2}{|c|}{ VECM } & & \\
\hline & \multirow{2}{*}{ IPI } & \multirow{2}{*}{ INF } & \multirow{2}{*}{ IPI } & \multirow{2}{*}{ INF } & \multicolumn{2}{|c|}{ IRF } & \multicolumn{2}{|c|}{ FEVD $(\%)$} & & \multirow{2}{*}{ IPI } & \multirow{2}{*}{ INF } & \multirow{2}{*}{ IPI } & \multirow{2}{*}{ INF } & \multicolumn{2}{|c|}{ IRF } & \multicolumn{2}{|c|}{ FEVD $(\%)$} \\
\hline & & & & & IPI & INF & IPI & INF & & & & & & IPI & INF & IPI & INF \\
\hline LnCLOAN & 0.07 & 0.00 & 0.42 & 0.24 & + & + & 4.94 & 11.03 & LnIFIN & 0.03 & 0.00 & 0.98 & 0.28 & - & - & 12.70 & 4.27 \\
\hline LnCDEP & 0.00 & 0.00 & 0.49 & 0.39 & - & + & 2.51 & 0.02 & LnIDEP & 0.68 & 0.00 & 0.37 & 0.53 & - & + & 7.01 & 40.75 \\
\hline PUAB & 0.04 & 0.00 & 0.80 & 0.36 & + & + & 55.51 & 8.95 & PUAS & 0.43 & 0.05 & 0.93 & 0.08 & + & - & 33.97 & 0.12 \\
\hline \multicolumn{18}{|c|}{ DUAL } \\
\hline LnIFIN & 0.99 & 0.00 & 0.08 & 0.31 & + & + & 2.11 & 1.43 & LnCDEP & 0.00 & 0.00 & 0.58 & 0.72 & - & & 17.89 & 1.1 \\
\hline LnCLOAN & 0.08 & 0.38 & 0.99 & 0.81 & - & - & 17.5 & 0.90 & PUAS & 0.02 & 0.62 & 0.33 & 0.11 & + & - & 7.0 & 0.71 \\
\hline LnIDEP & 0.05 & 0.26 & 027 & 0.73 & - & - & 1.78 & 0.17 & PUAB & 0.31 & 0.00 & 0.78 & 0.66 & + & - & 24.11 & 3.1 \\
\hline
\end{tabular}

LnIFIN in the dual model has more positive influence on IPI than its effect on INF, while LnCLOAN has more negative effects on IPI than its effect on INF. In the conventional model, LnCLOAN has a positive influence on INF more than its influence on IPI. And in the Islamic model, LnIFIN has a negative influence on IPI more than its effect on INF.

\section{CONCLUSIONS AND RECOMMENDATIONS}

This empirical paper illuminates several important findings. First, based on the Granger Causality Test results show that both LnCLOAN (credit) and LnIFIN (financing) variables are sustainable to output but are not sustainable to prices. This shows that the channels of credit and financing are still relevant to be used in the mechanism of monetary transmission on the monetary policy objective of increasing output, but the monetary transmission mechanism of credit channels and traditional financing is no longer effective on the monetary policy objective of inflation stability. As a result, a renewed monetary policy is desirable to affect inflation, as BI has done by implementing a mix of monetary policies (policy mix).

Second, based on the results of the study using three approaches (VECM, ECM, and ARDL), it shows that all conventional variables have a negative influence on economic growth and inflation but the negative effect on economic growth is greater than the negative effect on inflation, except the PUAB variable that gives positive influence of $24.11 \%$, whereas Islamic variables have a positive influence on economic growth and inflation. However, the positive influence on economic growth is greater than the positive influence on inflation. This positive influence on inflation shows that Islamic banking still has the potential to create money because it still resembles a conventional system that uses Lower Reserve Requirement (LRR) or Giro Wajib Minimum (GWM), and fiat money. Then with the absence of influence through the ARDL method, it can be concluded that the credit or financing channels are considered getting weaker in the monetary policy transmission mechanism.

Based on the findings, monetary policy could trigger economic growth, and the Islamic monetary policy model is considered to be more effective than the 
conventional monetary policy model, but it still has the potential to increase inflation. This shows that the distribution of financing besides being channeled to the real sector is also channeled to the financial sector, which in practice still resembles the conventional bank credit system. Thus, it still raises inflation. Therefore, Bank Indonesia should channel more funding to the real sector than the financial sector in order to achieve the objective of economic growth and controlled inflation.

Moreover, based on the results of the influence of credit and financing channels in previous research as in the study of Ascarya (2012), and a decrease in the magnitude of influence on economic growth, there is an influence of credit and financing through other market, such as the capital market and FinTech industry. The influence on economic growth is still dominated by credit and financing through banks, but it has been decreasing. Therefore, Bank Indonesia should anticipate the possibility of shifting the intermediary role of banks to other financial institutions, especially the FinTech industry. This study also entails further research especially that adding more variables, such as external economic factors, the number of data period, and the number of dual financial system countries.

\section{REFERENCES}

Abduh, M., and Azmi Omar, M. (2012). Islamic Banking and Economic Growth: The Indonesian Experience. International Journal of Islamic and Middle Eastern Finance and Management, 5(1), 35-47.https://doi.org/10.1108/17538391211216811 Agha, A., Ahmed, N., Mubarik, Y. A., and Shah, H. (2005). Transmission Mechanism of Monetary Policy in Pakistan. SBP-Research Bulletin, 1.

Amaluddin, F. (2007). Efektifitas Transmisi Kebijakan Moneter antara Bank Syariah dan Konvensionan. Tesis FE-UI.

Ascarya. (2009). Toward Optimum Synergy of Monetary Policy in Dual Financial / Banking System. Journal of Indonesian Economy and Business, 24(1), 33-48. Retrieved from https://journal.ugm.ac.id/jieb/article/view/6331/17950

Ascarya. (2011). Monetary Policy Transmission Mechanisms under Dual Financial System under Dual Financial System, (2).

Ascarya. (2012). Alur Transmisi dan Efektifitas Kebijakan Moneter Ganda di Indonesia. Buletin Ekonomi Moneter Dan Perbankan, 283-315.

Atcharariyachanvanich, W. (2004). VAR Analysis of Monetary Policy Transmission Mechanisms: Empirical Study on Five Asian Countries after the Asian Crisis. Forum of International Development Studies.

Bernoth, K., and Gebauer, S. (2017). Monetary Policy Implications of Financial Innovation. Monetary Policy Implication of Financial Inovation.

Boukhatem, J., and Ben Moussa, F. (2018). The Effect of Islamic Banks on GDP Growth: Some Evidence from Selected MENA Countries. Borsa Istanbul Review. https://doi.org/10.1016/j.bir.2017.11.004 Databoks, 2017. (n.d.).

Enders, W. (2004). Applied Econometric Time Series. Alabama: John Wiley and Son. Gujarati, D. N. (2004). Basic Econometrics (4th ed.). Singapore: McGraw-Hill Inc. 
Hamza, H., and Saadaoui, Z. (2017). Monetary Transmission Through The Debt Financing Channel of Islamic Banks: Does PSIA Play A Role? Research in International Business and Finance, 45, 557-570. https://doi.org/10.1016/j. ribaf.2017.09.004 Islamic Banking Act No 21 Year 2008, Pub. L. No. 21 (2008). Indonesia.

Jagtiani, J., and Lemieux, C. (2018). Do Fintech Lenders Penetrate Areas that are Underserved by Traditional Banks? Journal of Economics and Business. https:// doi.org/10.1016/j.jeconbus.2018.03.001

Kassim, M. S. A. M. S. H. (2015). Assessing The Contribution of Islamic Finance To Economic Growth. Journal of Islamic Accounting and Business Research. 6(2), 292-310. https://doi.org/10.1108/02656710210415703

Kia, A. (2014). Inflation: Islamic and Conventional Economic Systems - Evidence from the United States. International Journal of Economic Perspectives, 8(3), 18-40.

Lerskullawat, A. (2016). Effects of banking sector and capital market development on the bank lending channel of monetary policy: An ASEAN country case study. Kasetsart Journal of Social Sciences, 38(1), 9-17. https://doi.org/10.1016/j. kjss.2016.10.001

Loureiro, Y. K., and Gonzalez, L. (2015). Competition Against Common Sense: Insights On Peer-To-Peer Lending as a Tool to Allay Financial Exclusion. Marketing Intelligence and Planning, 33(5), 605-623. https://doi.org/10.1108/IJBM-062014-0065

Mishkin, F. S. (1995). Symposium on the Monetary Transmission Mechanism, 9(4), 3-10.

Mishkin, F. S. (1999). International Experiences with Different Monetary Policy Regimes. National Bureau of Economic Research Working Paper Series, (No. w6965).

Mishkin, F. S. (2006). Monetary Policy Strategy: How Did We Get Here? National Bureau of Economic Research Working Paper Series, (12515). https://doi. org/10.3386/w12515

Bank Indonesia. (2018). Monetary. Retrieved from https://www.bo.go.id/id/ moneter/Contents/Defaul.aspx

Montes, G. C., and Monteiro, G. G. do V. (2014). Monetary Policy, Prudential Regulation and Investment: Evidence from Brazil Considering The Bank Lending Channel. Journal of Economic Studies, 7(1), 63-83. https://doi.org/http:// dx.doi.org/10.1108/MRR-09-2015-0216

Nasution, M. E. (2007). Pengenalan Eksklusif Ekonomi Islam. Jakarta: Kencana.

Nazib, N. A., and Masih, M. (2017). The Response of Monetary Policy Shocks on Islamic Bank Deposits: Evidence From Malaysia Based on ARDL Approach. Munich Personal RePEc Archive Paper, (82094). Retrieved from https://mpra. ub.uni-muenchen.de/82094/

Peek, J., and Rosengren, E. S. (2013). The Role of Banks in the Transmission of Monetary Policy. Public Policy Discussion Papers, (13), 1-30. https://doi. org/10.1093/oxfordhb/9780199640935.013.0010

Pesaran, M. H., Shin, Y. (1999). An Autoregressive Distributed Lag Modelling Approach to Cointegration Analysis. Econometrics and Economic Theory in the 20th Century: The Ragnar Frisch Centennial Symposium., (March 3-5, 1995), 1-31. https://doi.org/10.1017/CCOL521633230 
Pohan, A. (2008). Kerangka Kebijakan Moneter dan Implementasinya di Indonesia. Jakarta: PT. RajaGrafindo Persada.

Pratiwi, A. (2016). Islamic Banking Contribution in Sustainable Socioeconomic Development in Indonesia: An Epistemological Approach. Humanomics, 32(2), 98-120. https://doi.org/10.1108/H-12-2015-0085

Sanfilippo-Azofra, S., Torre-Olmo, B., Cantero-Saiz, M., and López-Gutiérrez, C. (2017). Financial Development and The Bank Lending Channel in Developing Countries. Journal of Macroeconomics, 55, 215-234. https://doi.org/10.1016/j. jmacro.2017.10.009

Sharia Banking. (2018). Retrieved from https://www.bi.go.id/id/perbankan/ syariah/Contents/Default.aspx

Simpasa, A., Nandwa, B., and Nabassaga, T. (2015). Bank Lending Channel in Zambia: Empirical Evidence from Bank Level Data Anthony. International Journal for Researcher Development, 7(1), 63-83. https://doi.org/http://dx.doi. org/10.1108/MRR-09-2015-0216

Usman Ahmed, Thorsten Beck, C. M. S. S. (2015). Filling the Gap Filling the Gap How Technology Enables Access to Finance for Small- and Medium-Sized Enterprises. MIT Press Journal. https://doi.org/10.1162/inov_a_00239

Warjiyo, P. (2003). Kebijakan Moneter di Indonesia.

Warjiyo, P., Pendidikan, P., Studi, D. A. N., Ppsk, K., and Warjiyo, P. (2004). Mekanise Transmisi Kebijakan Moneter Di Indonesia.

Wijaya, A. R. (2009). Potensi Perbankan Syariah Terhadap Pertumbuhan Ekonomi. Detikcom. Retrieved from https:/news.detik.com/opini/d-1225941/potensiperbankan-syariah-terhadap-pertumbuhan-ekonomi-indonesia

Wulandari, R. (2012). Do Credit Channel and Interest Rate Channel Play Important Role in Monetary Transmission Mechanism in Indonesia?: A Structural Vector Autoregression Model. Procedia - Social and Behavioral Sciences, 65(ICIBSoS), 557-563. https://doi.org/10.1016/j.sbspro.2012.11.165

Yarasevika, S., Tongato, A., and Muthia, A. C. (2015). Bank Lending Channel in Indonesia's Monetary Policy Transmission Mechanism : A VECM approach. Proceedings of ISER 5th International Conference, Singapore, (September), 27-32. 
This page is intentionally left blank 